\section{Alvey lessons unheeded}

London

THE British government has failed to heed many of the lessons taught by the Alvey information technology programme, the largest single new British research initiative of the $1980 \mathrm{~s}$, according to the author of a new report on Alvey. Many of the problems that afflicted the $£ 350$-million Alvey programme still plague government-sponsored research programmes, says Luke Georghiou from the University of Manchester.

In particular, Georghiou finds that the Alvey programme did not live up to its billing as a boost to the competitiveness of British industry. The findings are of special interest now as the British government is considering reforms to its $£ 210$ million LINK initiative another programme of industrial/academic collaborative research that Georghiou says repeats many of Alvey's mistakes.

Georghiou and Ken Guy from the University of Sussex have just completed an independent evaluation of the Alvey programme, which ran from 1983 to 1988 . Their report, commissioned by the Department of Trade and Industry and the Science and Engineering Research Council, concludes that Alvey was highly successful in strengthening the British information technology research community, but that it failed to fulfil its broader aim of improving the commercial performance of the British information technology industry.

Over the past few years, the British computer industry has continued to decline, and the report says that few of the companies that participated in Alvey projects seem likely to gain commercially from Alvey research.

Alvey brought together researchers from different companies and from academic institutions to work on so-called 'precompetitive' research. It concentrated on research into integrated circuits, software engineering, artificial intelligence and the interaction between humans and computers. In addition to $£ 200$ million of public money, Alvey projects consumed some $£ 150$ million provided by industry. The goal of the programme was that companies that collaborated in research projects should later go their separate ways and turn the resulting technology into marketable products. But the second competitive phase rarely materialized.

A number of factors were to blame. Alvey should have been accompanied by a training programme to address skills shortages in the British information technology industry, Georghiou says. He also believes that the focus on pre-competitive research was too narrow. In those cases where companies need to pool their expertise to work on a research project, they will often also need to collaborate in bringing the results of that research to market, Georghiou says. He believes that support for this 'near market' research and development is necessary if programmes such as Alvey are to yield commercial results.

But since Alvey, the British government has actually reduced its support for nearmarket research. The Department of Trade and Industry's spending on industrial innovation, for example, dropped by some $£ 50$ million between 1987-88 and 1989-90. In recent months, the department has launched a small scheme to help fund the costs of developing commercial products in small companies (see Nature, 349, 556; 14 February 1991), but critics argue that this is too little, too late.

Brian Oakley, who headed Alvey's management team, agrees that the commercial exploitation of Alvey research has been disappointing, and blames a lack of incentive to invest in innovation. Over the past 20 years, he points out, the rate of interest on borrowed money in Japan has consistently been about one-third of that in Britain. This "climate of expensive money' in Britain has kept companies from investing in research, product development and training, Oakley says.

Improving the climate for investment in innovation in Britain is a formidable task. But Georghiou says many of the difficulties that hampered Alvey have been retained in the government's current LINK programme, on which the government plans to spend $£ 210$ million of public money between 1988 and 1993. LINK also aims to unite industrial researchers and academics in precompetitive research, but it is not restricted to any particular industrial sector.

In some cases, Georghiou says, the rules governing the LINK programme are more perverse than those that hampered Alvey. The government provided 50 per cent of the research costs of companies involved in Alvey projects, and Georghiou believes that even more generous support was needed in order to encourage more companies to take part. But, for LINK, the government will pay only half the total cost of each collaborative project, including the funds for both industry and academic researchers. As academic collaborators are usually funded in full, this means that companies participating in LINK projects must usually pay most of their own research costs.

Another difficulty with Alvey, according to Georghiou, was the decision to negotiate intellectual property rights agreements before starting each project. The basic arrangement was that individual property rights would lie with the industrial partners in each project. But some projects were delayed by 18 months as the collaborators argued over the rate of the royalties that would be paid to university-based researchers in the event of any commercial returns. LINK has been subject to similar delays.

Oakley defends his decision to negotiate individual property rights agreements at the start of each project, saying that the negotiation of these agreements at a later stage might have created further obstacles to commercial exploitation. Some of Oakley's former colleagues, however, agree with Georghiou. David Thomas, industrial liaison officer at Imperial College, London, and formerly an Alvey director, says the property rights issue "was an impossible problem".

The evaluation of Alvey and the criticisms of LINK are timely. The government is now considering its response to an independent review of LINK programme's management, commissioned because of the disappointingly slow take-up of LINK grants.

The LINK review, produced by the consultants Segal Quince Wicksteed, is to be published in the next few weeks, and its recommendations are thought to echo many of the criticisms voiced by Georghiou. The government may consider revising the rules governing individual property rights arrangements. But in the current harsh economic climate, a decision to increase the size of LINK grants made to the industrial collaborators in LINK projects is less likely, unless the number of new projects is to be reduced.

Peter Aldhous

\section{ANTHROPOLOGY}

\section{Bones go home}

\section{London}

THE University of Edinburgh is planning to return its collection of more than 300 Aoriginal bones to Australia. The decision, announced earlier this month, is a victory for Aboriginal civil rights campaigners, who will take custody of the bones, but the move has disappointed the small international community of physical anthropologists, who used the collection to study the interrelationships between Aboriginal tribes. The bones will be returned in several months' time, once they have been catalogued in full.

Loring Brace, from the Museum of Anthropology at the University of Michigan, says the Edinburgh collection, amassed during the late nineteenth century, is one of the world's finest.

Unusually, the vast majority of material in the collection is identified according to its region of origin. This allowed researchers to study the relationships between Aboriginal tribes, and their rate of evolution. "There is no comparable collection" of Australian Aboriginal bones, says Brace.

Some research should still be possible, by taking measurements from casts and photographs of the bones, but the loss of the original material will rule out any future genetic studies, made possible only recently by the advent of new DNA amplification techniques.

The University of Edinburgh decided in principle earlier this year to return human remains from its collection on request provided the remains were deemed to have cultural or religious significance to the group concerned.

Peter Aldhous 